\title{
STUDY REGARDING INTELLECTUAL PROPERTY QUALITY IN INDUSTRY
}

\author{
Mihail Aurel, ȚȚȚ ${ }^{1}$ and Constantin, OPREAN ${ }^{2}$ \\ ${ }^{1}$ Lucian Blaga University of Sibiu, Sibiu, Romania, e-mail: mihail.titu@ulbsibiu.ro \\ ${ }^{2}$ Lucian Blaga University of Sibiu, Sibiu, Romania, e-mail: constantin.oprean@ulbsibiu.ro
}

\begin{abstract}
The purpose of this article is to highlight the current situation in the field of automotive stressing the importance of quality and innovation in order to create competitive advantage. The main conclusion of this study is that organizations in the field of automotive technology that have implemented quality systems and valorize the intangible assets resources recorded an obvious success.
\end{abstract}

KEY WORDS: Intellectual property protection, Quality, Innovation, Quality Management.

\section{INTRODUCTION}

Knowledge represents the key resource of inventions and innovation by default. These are hard to imitate, transferred or substituted. Intensely knowledge-based industries, such as automotive industry are much more susceptible to innovative collaborations that bring multiple benefits to all those involved.

For a good knowledge of the dynamics of organizations and resources can no longer be successfully used the concept of "trader representative" because real economic processes are heterogeneous, with permanent innovations product and process. It is assumed that most easily harnessed innovations are technological innovation because they allow both the formulation of new technological processes, the emergence of new products, but also new knowledge that can accumulate to a technology, for an industry or for the world.

Great economists and researchers of this century have long predicted that the changes in the economy are both quantitative and qualitative, and the current neo-schumpeterian proposes as a tool for quantifying the effects of the economic concept of innovation.

Complex technologies from automotive industry amplify the collaborative efforts on the knowledge creation. With effort, any organization can maintain a role in the current competitive environment just relying on its activities of research and development. However, organizations do not have the ability to master all emerging technologies that may have a potential impact on the products [1].

Common projects of research and development, strategic alliances and other forms of collective innovation, make sharing of knowledge and competences possible [2]. Research and development processes involve common access to critical resources that most are not available.

Theorists' followers of neo-schumpeteriene theory emphasize the importance of opportunities for learning and knowledge transfer within the framework of the cooperation networks [3]. A positive principle of current neo-schumpeterian competition is that innovation takes place through price competition and becomes the dominant mechanism of coordination behavior of economic agents.

Within the industry added value and jobs for the labor force are created. The passage of time, causes to the organizations the accumulation of increasing knowledge about technology, while seeking to exploit through a profit as possible. In a quantitative growth, organizations gathered a growing stock of traditional production factors as economies of scale, had total production costs of the average lower in the long term, and the price was a sufficiently representative indicator for resource allocation in the economy.

In the automotive industry, an example of collaboration is the one in which Audi, BMW and Daimler have purchased digital maps division "Here" of the Finnish producer of telecommunications equipment and Nokia. This example shows the potential of innovation and orientation towards continuous improvement in order to obtain profit.

\section{QUALITY AND STATUS QUO IN AUTOMOTIVE INDUSTRY. CASE STUDY}

Quality system, as defined by the International Organization for Standardization (ISO) 9000 series of standards relating to quality management, has been developed in response to the challenges of globalization and increased market was unanimously accepted. ISO aims at facilitating the development and standardization of international goods and services.

Globally, the automotive industry calls for specific standards and for manufacturers of original equipment for motor vehicles and their suppliers of components or materials. Original equipment manufacturers and service providers recognize the importance of compliance to standards in order to remain competitive. The alignment of the system of quality 
management ISO 9001 at minimum requirements is also important to increase profitability by reducing problems and supply chain risks.

ISO/TS 16949 supplement the requirements of ISO 9001 for production in the automotive industry. Emerged from the need to have a harmonized global document for quality management system ISO/TS 16949, was developed by the International Automotive Task Force (IATF) and ISO Technical Committee. This technical specification combines all previous standards of quality, respective QS-9000, VDA 6.1, EAQF and AVSQ 94. Obtaining certification to ISO/TS 16949 demonstrates that the Organization in question meets the requirements for the quality management system to implement continuous improvement processes, with an emphasis on prevention of defects and reducing the generation of wastes and the variations in the supply chain. Technical requirements implemented are intended for all types of manufacturers and suppliers of products or materials, or services such as thermal treatments or galvanization, and other specified products by customers, such as parts of motor vehicles. Certification of compliance with these requirements is recognized by major auto manufacturers. Many of the major auto manufacturers work only with companies that have certification to ISO/TS 16949, and asks that in turn and their suppliers to adhere to strict technical specifications contained in this standard. So, it is evident the importance of quality in the automotive field.

The auto industry from Romania ran in the previous year, 2015 , cumulative business nearly to 90 billion lei from the production of automobiles and auto parts, the biggest players in the local market being Dacia on the production of cars and Continental on the production of components.

The top ten companies on the local market have run last year almost 31 billion lei, up 5\% compared to the previous year, the largest increase being dashed by the importers. But nearly twothirds of business represents the plant in Mioveni.

Although automobile sales continued to be on an increasing trend the market remains far from sales in the period before the crisis.

Among the viable solutions for the automotive industry to be maintained at a good level include transforming the program Rabla into a multiannual program, or focalization of secondhand imported cars. Another big problem is infrastructure. Romania needs to recover the gap in infrastructure (particularly road and rail), health, education, urban and regional development, energy, the restructuring of government management capacity and strengthening institutions of the state, and, in addition to the central authorities, an essential role it will have the initiative of the municipalities in order to promote such improvement projects through the absorption of Community funds at local and regional level. Must be viewed in perspective, and that analyzed recent years were not representative in terms of investment in infrastructure and this is a wake-up call in view of the desire to attract other potential investors.

The local auto industry relied in recent years on the production of cars, rather than the actual sale of cars in Romania. Although last year there were almost 120,000 sold vehicles, the volume remains far from a maximum of about 366,000 units sold in 2007, the year of the boom of the local car market.

Sales of motor vehicles increased last year by $20 \%$ compared to 2014 , to 120,591 units, according to manufacturers and importers Association (APIA), of which almost $80 \%$ were legal persons and individual's customers. Sales of trucks (commercial vehicles of more than 3.5 tons) increased over media market, after an advance of almost $38 \%$ to 7,400 units [4].

Dacia automobile manufacturer, the main constructor in the local market, last year recorded a turnover of over 19 billion lei (4.3 billion euros), up $2 \%$ compared to the previous year, when the company ran 18.8 billion lei, according to the company data [5]. The increase in the turnover of the company comes as car production in Mioveni has stalled last year about 339,000 units. Porsche Romania, the largest auto importer in the local market, took last year on business of 453 million euros (2 billion \$), up 14 percent, compared with 2014, company data show, surpassing for the first time since the crisis threshold of 450 mil. euro.

The figures for 2015, as reported by importers and traders of machines to the Ministry of public finance (MFP), show that last year the business had gone much better than in the previous one. That's without the 2014 has been a very difficult year for the industry. Well, in the Top 10 of the leading business figures, is Renault Commercial Roumanie, company responsible in Romania for Dacia brands Nissan and Renault. Division of the Renault group Romania, it achieved last year business worth 502 million euro, increasing by 19\% compared to 2014 .

The $2^{\text {nd }}$ place ranking in Romania is located, a division of the Porsche Porsche Holding GmbH headquartered in Salzburg, who manages the fate of Audi, Seat, Škoda, Volkswagen commercial vehicles, and Das WeltAuto (second-hand cars). It has recorded in 2015 a turnover of 454 million euros, up from 398 million in the previous year. The third place is occupied by the representation of Mercedes-Benz, which announced an increase of business with no less than $35 \%$ to 330 million euros. Otherwise all other companies in the Top 10 have reported increases in business figures, worthy of note being the increase of this indicator in the case of Rădăcini Motors, that has doubled.

Currently, VW, Audi, Seat and Skoda are represented nationally by 101 distributors. On every brand, VW brand has 22 dealers, Audi has a grid of 13 distributors, distributors network for Skoda comprises 32 centers, SEAT 12, and Volkswagen commercial vehicles are now 22.

Romania entered in 2015 in the rank of the biggest 10 machine manufacturers in Europe (table 1), by the number of vehicles manufactured, according to data presented at the Transportation and Mobility Solutions Experience Forum. It is estimated that by 2021 the biggest increases in the production of lightweight automobiles will record segments B (low grade) and $\mathrm{C}$ (compact), where fit the cars manufactured in Romania.

Table 1. Global car production

\begin{tabular}{|l|c|c|c|c|c|}
\hline No.crt. & Country & $\begin{array}{c}\text { Car } \\
\text { number }\end{array}$ & $\begin{array}{c}\text { Commercial } \\
\text { cars }\end{array}$ & Total & $\begin{array}{c}\% \\
\text { Difference }\end{array}$ \\
\hline 1. & Total & $68,539,516$ & $22,241,067$ & $90,780,583$ & $1.10 \%$ \\
\hline 2. & China & $21,079,427$ & $3,423,899$ & $24,503,326$ & $3.30 \%$ \\
\hline 3. & Japan & $7,830,722$ & $1,447,516$ & $9,278,238$ & $-5.10 \%$ \\
\hline 4. & Germany & $5,707,938$ & 325,226 & $6,033,164$ & $2.10 \%$ \\
\hline 5. & USA & $4,163,679$ & $7,936,416$ & $12,100,095$ & $3.80 \%$ \\
\hline 6. & $\begin{array}{l}\text { South } \\
\text { Korea }\end{array}$ & $4,135,108$ & 420,849 & $4,555,957$ & $0.70 \%$ \\
\hline
\end{tabular}




\begin{tabular}{|l|c|c|c|c|c|}
\hline No.crt. & Country & $\begin{array}{c}\text { Car } \\
\text { number }\end{array}$ & $\begin{array}{c}\text { Commercial } \\
\text { cars }\end{array}$ & Total & $\begin{array}{c}\text { \% } \\
\text { Difference }\end{array}$ \\
\hline 7. & India & $3,378,063$ & 747,681 & $4,125,744$ & $7.30 \%$ \\
\hline 8. & Spain & $2,218,980$ & 514,221 & $2,733,201$ & $13.70 \%$ \\
\hline 9. & Brazil & $2,018,954$ & 410,509 & $2,429,463$ & $-22.80 \%$ \\
\hline 10. & Mexico & $1,968,054$ & $1,597,415$ & $3,565,469$ & $5.90 \%$ \\
\hline 11. & UK & $1,587,677$ & 94,479 & $1,682,156$ & $5.20 \%$ \\
\hline 12. & France & $1,553,800$ & 416,200 & $1,970,000$ & $8.20 \%$ \\
\hline 13. & Czech & $1,298,236$ & 5,367 & $1,303,603$ & $4.20 \%$ \\
\hline 14. & Rep. & $1,214,849$ & 169,550 & $1,384,399$ & $-26.60 \%$ \\
\hline 15. & Slovakia & $1,000,001$ & 0 & $1,000,001$ & $3.00 \%$ \\
\hline 16. & Canada & 888,565 & $1,394,909$ & $2,283,474$ & $-4.60 \%$ \\
\hline 17. & Iran & 884,866 & 97,471 & 982,337 & $-9.90 \%$ \\
\hline 18. & Indonesia & 824,445 & 274,335 & $1,098,780$ & $-15.40 \%$ \\
\hline 19. & Turkey & 791,027 & 567,769 & $1,358,796$ & $16.10 \%$ \\
\hline 20. & Thailand & 772,250 & $1,143,170$ & $1,915,420$ & $1.90 \%$ \\
\hline 21. & Others & 693,817 & 138,866 & 832,683 & $19.10 \%$ \\
\hline 22. & Italy & 663,139 & 351,084 & $1,014,223$ & $45.30 \%$ \\
\hline 23. & Malaysia & 558,324 & 56,347 & 614,671 & $3.30 \%$ \\
\hline 24. & Poland & 534,700 & 125,903 & 660,603 & $11.30 \%$ \\
\hline 25. & Hungary & 491,720 & 3,650 & 495,370 & $13.20 \%$ \\
\hline $\mathbf{2 6 .}$ & Romania & $\mathbf{3 8 7 , 1 7 1}$ & $\mathbf{6}$ & $\mathbf{3 8 7 , 1 7 7}$ & $\mathbf{- 1 . 1 0 \%}$ \\
\hline 27. & Belgium & 369,172 & 40,168 & 409,340 & $-20.80 \%$ \\
\hline 28. & South & 341,025 & 274,633 & 615,658 & $8.80 \%$ \\
\hline & ffrica & & & & \\
\hline
\end{tabular}

state granted; local links of chains of suppliers will multiply on the basis of the growth of the workforce innovation of local auto suppliers, but also easier access to loans; they will record more indigenous capital investment in the area of SMEs, due to the high degree of accessibility to European funds earmarked for competitiveness and the development of collaboration between SMEs and technical universities. All these actions could change the order on top brands with the highest sales in Europe (table 2).

Table 2. Car producers with highest sell in Europe

\begin{tabular}{|c|c|c|c|c|}
\hline \multirow{2}{*}{ No. crt. } & \multirow{2}{*}{ Brand } & Sales 2015 & Sales 2014 & $\%$ Difference \\
\hline & & $14,202,024$ & $13,006,885$ & 9.2 \\
\hline & VOLKSWAGEN & $1,727,094$ & $1,621,224$ & 6.5 \\
\hline & FORD & $1,020,875$ & 940,242 & 8.6 \\
\hline & RENAULT & 975,450 & 877,091 & 11.2 \\
\hline & OPEL/VAUXHALL & 942,128 & 886,450 & 6.3 \\
\hline & PEUGEOT & 856,091 & 786,176 & 8.9 \\
\hline & AUDI & 767,173 & 726,144 & 5.7 \\
\hline & BMW & 748,176 & 676,618 & 10.6 \\
\hline & MERCEDES & 737,278 & 652,373 & 13 \\
\hline & FIAT & 656,669 & 586,294 & 12 \\
\hline & SKODA & 617,636 & 582,241 & 6.1 \\
\hline & TOYOTA & 565,317 & 534,232 & 5.8 \\
\hline & NISSAN & 557,354 & 479,299 & 16.3 \\
\hline & CITROEN & 549,684 & 525,151 & 4.7 \\
\hline & HYUNDAI & 470,130 & 424,021 & 10.9 \\
\hline & KIA & 384,790 & 353,719 & 8.8 \\
\hline & DACIA & 382,948 & 364,219 & 5.1 \\
\hline & SEAT & 338,383 & 328,246 & 3.1 \\
\hline & MAZDA & 211,391 & 174,628 & 21.1 \\
\hline & MINI & 187,706 & 156,908 & 19.6 \\
\hline & SUZUKI & 181,456 & 162,335 & 11.8 \\
\hline
\end{tabular}

Source: The European Automobile Manufacturers' Association [7]

As can be seen in table with number 2, BMW and Mercedes have had strong sales and have narrowed the gap towards the Audi, which was among the worst increase in sales of the top 10 brands.

In the light of table 2 it should be noted that in terms of brand value ranking is quite another. The highest value is for the Toyota brand, followed by BMW and Mercedes-Benz (table 3). It should be said that the brand value differs. The rank made by Forbes [8], emphasize that Apple is on the first place and Toyota is placed on 6, followed by BMV on 14 and MercedesBenz on 20.

The likely trends for local auto industry are: development of digitalization for the concept of optimization technologies, products, logistics, lean production, but also for the coinnovation of the components in the chains of suppliers; the emergence of new investment and research and development activities, private car, driven by improved cooperation between industry and public research-development and support of real 
Table 3. Brand value

\begin{tabular}{|c|c|c|c|c|c|}
\hline \multirow[b]{3}{*}{$\begin{array}{l}\text { No. } \\
\text { crt. }\end{array}$} & \multirow[b]{3}{*}{ BRAND } & BRAND & VARIATION & \multirow[b]{3}{*}{ COUNTRY } & ACTIVITY \\
\hline & & VALUE & $2015 / 2016$ & & SECTOR \\
\hline & & \multicolumn{2}{|l|}{$\begin{array}{l}\text { (in billions } \\
\$ \text { ) }\end{array}$} & & \\
\hline 1 & $\begin{array}{l}\text { Apple / } \\
\text { Google }\end{array}$ & $\begin{array}{l}231.9 / \\
229.2 \\
\end{array}$ & - & SUA & Technology \\
\hline 2 & $\begin{array}{l}\text { Google / } \\
\text { Apple }\end{array}$ & $\begin{array}{l}229.2 / \\
228.5 \\
\end{array}$ & - & SUA & Technology \\
\hline 3 & Microsoft & 121.8 & $5 \%$ & SUA & Technology \\
\hline 4 & AT\&T & 107.4 & $20 \%$ & SUA & Telecom \\
\hline 5 & Facebook & 102.5 & $44 \%$ & SUA & Technology \\
\hline 6 & Visa & 100.8 & $10 \%$ & SUA & $\begin{array}{l}\text { Credit } \\
\text { cards }\end{array}$ \\
\hline 7 & Amazon & 99 & $59 \%$ & SUA & Retail \\
\hline$\ldots$ & & & & & \\
\hline 28 & Toyota & 29.5 & $2 \%$ & Japan & Auto \\
\hline 33 & BMW & 26.8 & $2 \%$ & Germania & Auto \\
\hline 39 & $\begin{array}{l}\text { Mercedes- } \\
\text { Benz }\end{array}$ & 22.7 & $4 \%$ & Germania & Auto \\
\hline 74 & Honda & 13.2 & $-1 \%$ & Japan & Auto \\
\hline 75 & Ford & 13.1 & $0 \%$ & SUA & Auto \\
\hline 92 & Nissan & 11.5 & $1 \%$ & Japan & Auto \\
\hline
\end{tabular}

Source: Top 100 Most Valuable Global Brands [9]

European automobile industry invests 44.7 billion euros in research and development every year, about $5 \%$ of the total turnover of the industry as a whole. Vehicle manufacturers are a driving force for innovation in Europe is the leading research and development vehicles ever safer, and with improved production processes, logistics and mobility management. More efficient vehicles are a direct result of previous investments in research and development. They are also proof of innovation that characterizes a European automotive sector extremely competitive. The automotive industry is applying for 6000 patents annually. Typically, the process of research and development is a long-term strategic process. Automobile production is based on significant investment and, increasingly more on partnerships with stakeholders. Therefore, it takes time to realize products capable to undergo rigorous testing to ensure technologies ready for production. Bringing to market new technologies takes time and repeated tests. Considering the evolution of the number of patents for invention filed, one can say that the interest in this area is on an upward trend (Figure 1). As can be seen, in the last years China is the one that show the most interest for innovation in this field followed by United States of America. But despite this in an economic universe of such commingled control and freedom, it is extremely difficult to determine how a single element such as patents has affected competition. The automobile industry itself is a primary factor in the operation of the industrial system. The demands which it makes upon raw materials, fabricated products, and corollary goods and services speak of its critical importance in the industrial structure. The fluctuations in its output, prices, and employment at any given time are readings of the pulse of the economy and portents of its immediate future. Obviously, such an industry has a very high coefficient of patentability. If it is considered that more than fifteen thousand items are assembled in an automobile, drawing upon a large number of mechanical, electrical, and chemical industries, it would seem inevitable that patent problems would pose continuous difficulty to the industry. In some phases of its activities the automobile industry is an example par excellence of extreme integration, both vertical and horizontal. In still other phases it has maintained a competitive ebb and flow of market relations. It has had trade groupings and associations almost continuously since its foundation, but it has also had conspicuous and ever-present challengers to any concert of interests [10].

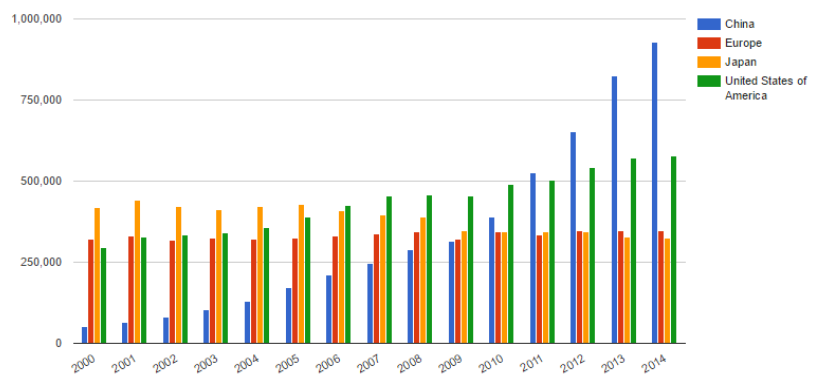

Table 4. The evolution of automotive patents

$\begin{array}{lll}\text { Source: } & \text { WIPO } & \text { Statistics } \\ \text { http://ipstats.wipo.int/ipstatv2/ipsBarchartval }\end{array}$

Transport and mobility are a prerequisite for economic prosperity and social activity, but it also presents significant challenges for sustainable development. In the decades to come, research and development in motorization will focus on areas such as rationalization of transport, improving road safety and focusing on the environmental impact of increased mobility needs. As can be seen in Figure 2, the organization with the most patent applications filed and Bosch are Toyota, Hyundai. Making a correlation between the number of patents and brand value (table 3 ) you can see a direct link in the case of Toyota. Patents for invention in the field of automotive industries can be subdivided, as can be seen in Figure 2. The largest number of patents being filed for propulsion, navigation, manipulation, and safety and security.

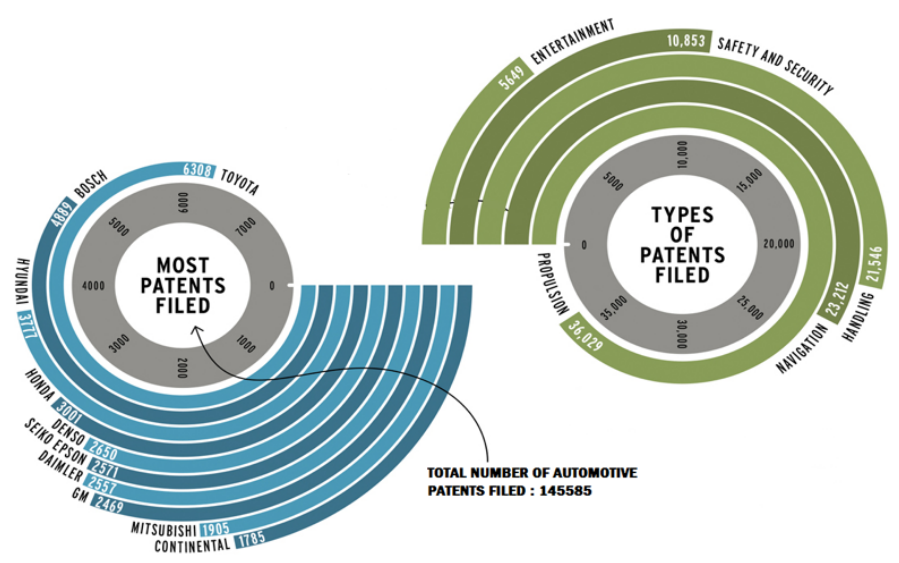

Figure 1. Patents number in automotive industry

Source: http://ajelnewsyemen.com/1061527/details [12]

The value of investments in the manufacture of automotive components is higher relative to other countries in the area of Central and Eastern Europe, local suppliers are already starting to invest in innovation and upgrading technology. However, do not allow investments still capitalizing on the potential development of the whole sector in Romania. 
That's why it requires the involvement of multinationals in the field of automotive technology in transferring skills, educational partnerships with universities and student involvement and academia in the research and development processes [13].

With regard to the significant technological developments in automotive industry from Romania we can mention: manufacture of organic generation engines, production of gearboxes for cutting-edge international builders, microelectronics and mechatronics advanced (including research and development), advanced technology and auto components from plastic masses, rubber and composite, increasing the number of robots use on production lines.

For Romania, the current competitive advantages in the cost of labor and utilities will gradually diminish in the future, so that new investments and capacity developments will be targeted towards new products and technologies globally competitive, with high added value.

It can be said that those of auto parts companies focused on innovation are more profitable than those specialized in certain technologies. The reasons are listed in figure 3.

\begin{tabular}{|c|}
\hline Innovation of components allows the use of multiple \\
assemblies.
\end{tabular}

\section{CONCLUSIONS}

Creative ideas and innovative solutions are found to be crucial to leave the shadow of the classification as modest innovator hat Romania received. The automotive industry is the solution for attracting new investment leading to maximize the achievements in the field of research and innovation.

Unconventional thinking is important. Innovation means developing technologies to help people and to make a living. Innovators must always be prepared to discover unexpected answers to well-known problems.

Innovation and quality are the key to our future life standards, Romania, therefore, need to be more inventive, innovate more and react better to market trends. Although the capacity of innovation depends on a great many factors, harnessing creativity is by far the most important. Quality-innovation relationship requires smart investments that can bring new and sustainable solutions and benefits to our societies and economies.

Statistics presented demonstrates that partnerships between various sectors, should be encouraged in the same way that should permit the development of certification which consolidated a society directed towards quality.

To become a competitive advantage, innovation and actions directed towards quality must overcome the isolated actions stages of accidental and personal initiatives, they must become a mass phenomenon, characterizing the approach of most organizations.

\section{REFERENCES}

1. Birch all, D.W., Tovstiga, G., Chanaron, J.J., Capabilities in strategic knowledge sourcing and assimilation: a new look at innovation in the automotive industry, International Journal of Automobile Technology Management, Vol.1, No.1, pp. 78-91, (2001).

2. David, J. Teece., Competition, cooperation, and innovation: organizational arrangements for regimes of rapid technological progress, Journal of Economic Behavior \& Organization, Vol.18, No.1, pp. 1-25, (1992).

3. Hanusch, H., Pyka, A., Principles of Neo-Schumpeterian Economics, Cambridge Journal of Economics, Oxford University Press, Vol.31, No.2, pp. 275-289, (2007).

4. ***Buletin statistic Auto APIA, available at http://www.apia.ro/publicatii/buletin-statistic/.

5. ***Vânzări Dacia în anul 2015, available at http://www.daciagroup.com/comercial/vanzari-daciavanzari-2015.

6. $* * *$ The International Organization of Motor Vehicle Manufacturers, http://www.oica.net/category/productionstatistics/

7. $* * *$ The European Automobile Manufacturers' Association, http://www.acea.be/

8. ***Forbes, The World's Most Valuable Brands Of 2016, http://www.forbes.com/powerful-brands/list/\#tab:rank

9. ***Top 100 Most Valuable Global Brands, http://wppbaz.com/admin/uploads/files/BZ Global 2016 Report.pdf

10. Welsh, C., Patents and Competition in the Automobile Industry, Vol.13, No.2, pp. 261, (1948),

11. ***WIPO http://ipstats.wipo.int/ipstatv2/ipsBarchartval

12. ***Automotive patenting trends, http://ajelnewsyemen.com/1061527/details

13. Kramer, Jan-Philipp., Diez, Javier Revilla., Marinelli, Elisabetta., Iammarino, Simona., Intangible assets and MNEs' locational strategies for innovation or: Why the regional matters, Jahrbuch für Regionalwissenschaft, Vol.30, No.2, pp. 129-157, (2010). 